\title{
Cold Hardiness of Floral Buds of Deciduous Azaleas: Dehardening, Rehardening, and Endodormancy in Late Winter
}

\author{
Scott R. Kalberer and Rajeev Arora ${ }^{1}$ \\ Department of Horticulture, 106 Horticulture Hall, Iowa State University, Ames, IA 50011-1100 \\ Norma Leyva-Estrada \\ Department of Statistics, Iowa State University, Ames, IA 50011-1100 \\ Stephen L. Krebs \\ The Holden Arboretum, 9500 Sperry Road, Kirtland, OH 44094-5172
}

AdDitional INDEX words. Rhododendron, budbreak, chilling requirement, deacclimation, freezing tolerance, reacclimation

\begin{abstract}
Dehardening resistance and rehardening capacity in late winter and spring are important factors contributing to the winter survival of woody perennials. Previously the authors determined the midwinter hardiness, dehardening resistance, and rehardening capacities in deciduous azalea (Rhododendron L.) floral buds in early winter. The purpose of this study was to investigate how these parameters changed as winter progressed and to compare rehardening response at three treatment temperatures. Experiments were also conducted to measure bud water content during dehardening and chilling accumulation of 10 azalea genotypes. Buds of $R$. arborescens (Pursh) Torr., $R$. canadense (L.) Torr., R. canescens (Michx.) Sweet, and R. viscosum (L.) Torr. var. montanum Rehd. were acclimated in the field and were dehardened in the laboratory at controlled warm temperatures for various durations. Dehardened buds were rehardened for 24 hours at 2 to $4^{\circ} \mathrm{C}, 0^{\circ} \mathrm{C}$, or $-2^{\circ} \mathrm{C}$. Bud hardiness $\left(\mathrm{LT}_{50}\right)$ was determined from visual estimates of freeze injury during a controlled freeze-thaw regime. The midwinter bud hardiness in the current study was $\approx 4$ to $8^{\circ} \mathrm{C}$ greater than in early winter. $R$. canadense and $R$. viscosum var. montanum dehardened to a larger extent in late winter than in the early winter study whereas $R$. arborescens and $R$. canescens did not. The rehardening capacities were larger in early than in late winter. Even though rehardening occurred throughout the first 8 days of dehardening (DOD) in early winter in the previous study, in the current study it was only observed after 10 DOD ( $R$. viscosum var. montanum) or 15 DOD ( $R$. arborescens). There was no difference among the rehardening capacities at the three rehardening temperatures for any genotype. Water content decreased throughout dehardening in all four genotypes examined. $R$. canadense had the lowest chilling requirement $(C R)$ [450 chilling units (CU)], followed by $R$. atlanticum (Ashe) Rehd., $R$. austrinum (Small) Rehd., $R$. canescens, and $R$. calendulaceum (Michx.) Torr. with intermediate CR [820, 830, 830, and 1000 CU respectively). The CR of $R$. arborescens, $R$. prinophyllum (Small) Millais, $R$. prunifolium (Small) Millais, $R$. viscosum var. montanum, and $R$. viscosum var. serrulatum (Small) Millais exceeded $1180 \mathrm{CU}$. Results of this study indicate that the dehardening kinetics (magnitude and rate) and the rehardening capacity of azalea buds are influenced by the progression of winter and the depth of endodormancy.
\end{abstract}

The winter hardiness of woody perennials is dependent on a variety of factors, including overall health and vigor, dormancy status, maximal cold hardiness, and resistance to additional nontemperature stressors. Of particular concern are the induction, kinetics, and magnitude of cold hardiness transitions [i.e., hardening (acclimation), dehardening (deacclimation), and rehardening (reacclimation)]. Although "hardening" and "dehardening," respectively, are an increase in freezing tolerance over time in response to inductive conditions and the reduction in acclimated hardiness in response to warm temperatures, growth, or development (Kalberer et al., 2006b), "rehardening" refers to the restoration of at least a portion of the lost hardiness after reversible dehardening and subsequent exposure

Received for publication 10 Aug. 2006. Accepted for publication 1 Oct. 2006. A contribution of the Iowa Agriculture and Home Economics Experiment Station, Ames, Iowa, Project No. 3601. Research was supported by Hatch Act and State of Iowa funds, the USDA Woody Landscape Plant Crop Germplasm Committee, and the Iowa Nursery \& Landscape Association Research Corporation.

We thank The Holden Arboretum and its employees for supplying facilities and resources for this project.

${ }^{1}$ Corresponding author: Department of Horticulture, 106 Horticulture Hall, Iowa State University, Ames, IA 50011-1100. E-mail: rarora@iastate.edu. to low temperatures. The existence of high dehardening resistance and rehardening capacities in late winter and spring are often important in preventing damage from frosts that follow periods of unseasonable, transient warm spells (Kalberer et al., 2006b; Pellett, 1998). Yet dehardening and rehardening physiology have received less attention than has initial hardening.

Research shows that endodormancy in woody perennials affects both absolute hardiness and hardiness transitions during annual cycles. Active development (lack of dormancy) promotes dehardening and also the irreversibility of dehardening (i.e., reduces rehardening capacity) (Mahfoozi et al., 2001; Rapacz, 2002). Rehardening represents a significant winter survival strategy for plants that quickly deharden upon exposure to high temperatures, and has been observed in dormant floral buds of many species (Andrews and Proebsting, 1987; Graham and Mullin, 1976; Kalberer et al., 2006a; Väinölä et al., 1997). However, the capacity for rehardening is not unlimited and it may not completely reverse dehardening (Hamilton, 1973; Repo, 1991). Moreover, rehardening capacity often declines during dehardening with increasing exposure to a given high temperature (Hamilton, 1973; Howell and Weiser, 1970) or as the dehardening temperature increases (Gusta and Fowler, 1976b). 
In our previous study (Kalberer et al., 2006a), the acclimated (i.e., midwinter) hardiness, dehardening kinetics, and rehardening capacities of nine genotypes of deciduous azaleas were estimated under controlled conditions using floral buds collected in late Dec. 2004. Our data showed that the ability to reharden was still evident in Rhododendron canadense and $R$. viscosum even after 8 d of dehardening (DOD), but we could not establish an explicit relationship between the extent of dehardening and subsequent rehardening capacity.

The current study was intended to supply more information on deciduous azalea dehardening and rehardening to resolve ambiguities and unanswered questions that arose from the earlier study (Kalberer et al., 2006a). One objective in this study was to estimate the acclimated (midwinter) hardiness, moisture content, dehardening kinetics, and rehardening capacities in azalea floral buds collected later during the winter season (late February) than in Kalberer et al. (2006a). These buds were expected to have emerged from endodormancy (completely or to a greater degree than the buds collected in Dec. 2004) and thus were expected to have reduced dehardening resistance and rehardening capacities. We expected the rehardening capacity to decrease with increasing duration of dehardening, but remain evident throughout the time course. We predicted that rehardening capacity would be affected by the rehardening temperature, with lower temperatures resulting in greater rehardening. Increasing moisture content was predicted to parallel the decreasing hardiness of buds throughout dehardening; dehardening and rehardening of immature flowers within dormant buds has been shown to cause water content to increase and decrease respectively (Andrews and Proebsting, 1987; Ishikawa and Sakai, 1981). A second objective was to determine the chilling requirement (CR) of floral buds in azalea genotypes used in our investigations. We believed that the CR would be associated both with the biogeography of the azaleas and with their observed dehardening and rehardening behavior.

\section{Materials and Methods}

SOURCES AND HANDLING OF FLORAL BUDS. Ten to 20 plants representing each of the deciduous azalea species were purchased as balled and burlap-wrapped shrubs (propagated from the bulked seed collected from intraspecific pollinations) from Natural Landscapes Nursery (West Grove, Pa.) and planted in Sept. 2004 at the David Leach Research Station of the Holden Arboretum in Madison, Ohio. Original seed for the plantings at Natural Landscape Nursery was collected in the wild from a defined area representing each of these species; see Kalberer et al. (2006a) for information on seed provenances. Plants were watered as needed. We used four azalea genotypes in the dehardening and rehardening study: $R$. arborescens, $R$. canadense, $R$. canescens, and $R$. viscosum var. montanum. The water content study included $R$. arborescens, $R$. canadense, $R$. viscosum var. montanum, as well as $R$. viscosum var. serrulatum, which was too cold sensitive in Feb. 2006 to use for hardiness studies. The budbreak study used all the former genotypes as well as $R$. atlanticum, $R$. austrinum, $R$. calendulaceum, $R$. prinophyllum, and $R$. prunifolium.

Plants underwent natural cold hardening in the field until floral buds with 3 to $12 \mathrm{~cm}$ of attached stem were collected on 22 Feb. 2006. Buds were stored in ice-filled coolers, immediately transported to the laboratory, and stored under ice in a cold room ( 2 to $4{ }^{\circ} \mathrm{C}$ ) overnight before starting the dehardening regime.
Dehardening AND ReHARDENing treatments. After setting aside buds for estimations of acclimated cold hardiness (0 DOD), the remainder of the buds were prepared for dehardening. Bud stems were pruned under water to prevent embolisms, inserted into water-saturated foam florist blocks, and stored in plastic bins (Kalberer et al., 2006a) before being placed in an environmentally controlled growth chamber. The dehardening treatment consisted of a 14-h photoperiod (provided by cool-white fluorescent lamps) with a $24{ }^{\circ} \mathrm{C}$ day $/ 18{ }^{\circ} \mathrm{C}$ night regime. Sets of 32 buds per species after $0,2,5,10$, and 15 DOD were used for cold hardiness estimations. Rhododendron canadense was only dehardened up to 10 DOD (because of budbreak by that time), and $R$. canescens was only dehardened for 5 DOD because of a lack of buds.

To evaluate the rehardening capacity of buds (i.e., the increase in hardiness of dehardened buds after reexposure to cold) 32-bud sets of all genotypes were rehardened after 2, 5, 10, and 15 DOD at three rehardening temperature treatments each lasting $24 \mathrm{~h}$. The warmest rehardening temperature $\left(2\right.$ to $\left.4{ }^{\circ} \mathrm{C}\right)$ was applied in the cold room and a $0^{\circ} \mathrm{C}$ treatment was applied by burying the buds in ice. The coldest rehardening treatment (30 min at $4{ }^{\circ} \mathrm{C}, 30 \mathrm{~min}$ at $0{ }^{\circ} \mathrm{C}, 23 \mathrm{~h}$ at $-2{ }^{\circ} \mathrm{C}$ ) was administered by placing bud stems into test tubes containing $1 \mathrm{~mL}$ water and cooling them in a programmable glycol bath (Kalberer et al., 2006a).

Cold HARDiness Evaluations. Hardiness was evaluated at one control $\left(2\right.$ to $\left.4{ }^{\circ} \mathrm{C}\right)$ and seven subfreezing temperatures. Preparation of buds for controlled freezing was as described in Kalberer et al. (2006a); however, four bud replicates were used at each temperature. The programmed freezing protocol constituted two linear temperature ramps; a cooling rate of $-1{ }^{\circ} \mathrm{C} / \mathrm{h}$ over the first 3 to $4 \mathrm{~h}$ of the experiment (to induce ice nucleation) followed by $-3{ }^{\circ} \mathrm{C} / \mathrm{h}$ thereafter. Ice nucleation, which was determined by exotherms, normally occurred between $-2.5{ }^{\circ} \mathrm{C}$ and $-3.5^{\circ} \mathrm{C}$. The buds were removed at the respective profile temperatures and placed on ice for overnight thaw. Subsequently, they were transferred to $4{ }^{\circ} \mathrm{C}$ for $3 \mathrm{~h}$ and then incubated at $27^{\circ} \mathrm{C}$ for at least $3 \mathrm{~d}$ before examining bud damage, as in Kalberer et al. (2006a).

Statistical AND WATER CONTENT ANALySES. The dehardening and rehardening experiments were completely randomized designs with genotype, DOD, and rehardening temperature as treatments. Data were analyzed using SAS (version 9.1; SAS Institute, Cary, N.C.). Logistic models described the logit of proportion floret injury within a bud as a linear function of temperature for each combination of genotype and DOD. The logistic models were solved for the $\mathrm{LT}_{50}$ (the temperature killing $50 \%$ of florets in degrees Celsius), an estimate of hardiness. Rehardening capacities were calculated as the difference between $\mathrm{LT}_{50}$ values estimated before and after rehardening at a particular DOD. Differences in hardiness $\left(\mathrm{LT}_{50}\right)$ or rehardening capacity among treatment combinations were determined using an LSD procedure [see Kalberer et al., (2006a) for further details about the statistical analysis].

Water content was measured throughout the time course for four genotypes. The fresh weight of each of 10 buds was measured after $0,2,5,10$, and 15 DOD. The buds were ovendried (Isotemp 500 Oven; Fisher Scientific, Pittsburgh, Pa.) for $3 \mathrm{~d}$ at $62{ }^{\circ} \mathrm{C}$ and were used to measure the dry weight. The water content of each bud (one bud/replicate, 10 replicates) was then calculated (water weight as a percentage of fresh weight).

ESTIMATION OF CHILling REQUIREMENTS. Beginning on 14 Nov. 2005 and ending on 13 Mar. 2006, eight floral buds with 
attached stems from each of 10 genotypes were collected at weekly intervals for a budbreak assay. Bud stems were immersed in cups filled with a lemon-lime soda solution $(5 \%$ $\mathrm{v} / \mathrm{v}$, to provide sugars for forcing and acidity to control bacterial/fungal growth at the stem base) and the bases were clipped underwater twice per week to prevent xylem embolisms. Buds were kept inside a "tent" of translucent plastic wrap at room temperature $\left(25^{\circ} \mathrm{C}\right)$ with cool white fluorescent lighting for $24 \mathrm{~h} / \mathrm{d}$ and were misted two to three times daily to maintain a high humidity.

Daily observations were made of bud swelling and opening of the scales, with observations recorded for the largest terminal bud if there was more than one bud per stem. Buds exhibiting swelling or scale opening were classified as "broken." The percentage budbreak was calculated after 4 weeks. Ambient temperatures were measured at the plant growth site every 30 min using a data logger (HOBO H8 Pro; Onset Computer Co., Bourne, Mass.) from 16 Oct. 2005 to 13 Mar. 2006. Each recorded temperature was converted to chilling units (CU) according to the Utah model (Richardson et al., 1974) and the cumulative CUs were summed for each bud sampling date. The percentage budbreak was plotted as a function of CU to a best-fit sigmoidal curve. The CR (i.e., the number of CU accumulated to cause $50 \%$ budbreak) was estimated from these plots (Fig. 1).

\section{Results}

Dehardening PatTerns. At 0 DOD the ranking of hardiness in azalea genotypes from most to least was as follows: $R$. viscosum var. montanum $>R$. canadense $>R$. arborescens $>$ $R$. canescens (Table 1). The relative hardiness of the genotypes shifted during the time course as dehardening progressed. Rhododendron canadense was hardier than $R$. canescens at 0 DOD, but this relative ranking reversed by 5 DOD (Table 1). Although $R$. viscosum var. montanum was hardier than $R$. arborescens at 0 DOD, the two genotypes were equally hardy at 2 DOD, and by 10 DOD $R$. arborescens was hardier than $R$. viscosum var. montanum (Table 1). Rhododendron viscosum var. montanum and $R$. arborescens steadily dehardened from 0 DOD up to 15 DOD as did $R$. canadense from 0 DOD up to 5 DOD (Table 1). Rhododendron canescens did

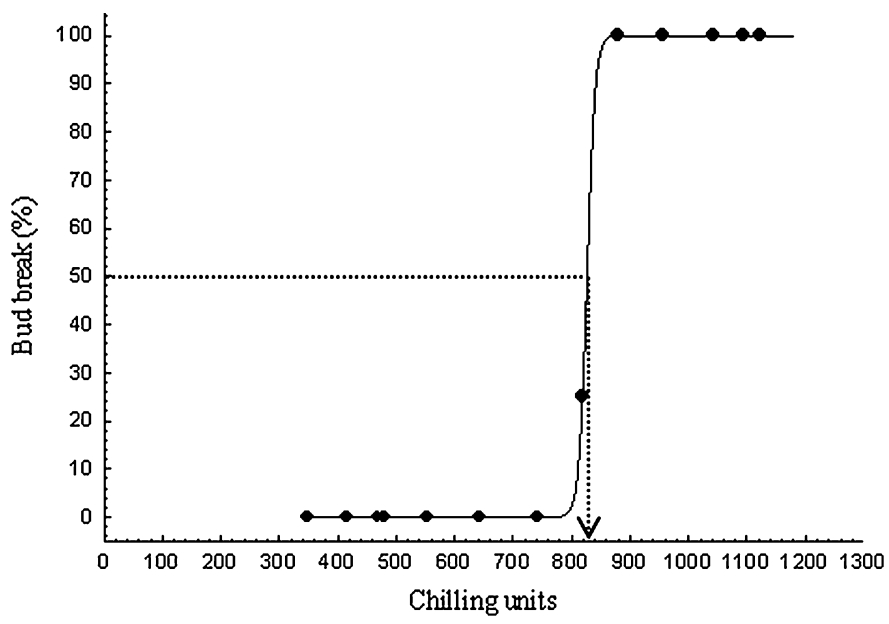

Fig. 1. Percentage bud break as a function of chilling unit accumulation for Rhododendron canescens. The best-fit line used to estimate the chilling requirement for breaking dormancy ( $50 \%$ budbreak) is shown. not lose hardiness during the first 2 DOD but dehardened between 2 and 5 DOD (Table 1).

The genotypes varied in their rate of dehardening (Table 1). Rhododendron canadense dehardened rapidly by losing $7.7^{\circ} \mathrm{C}$ and $18.3{ }^{\circ} \mathrm{C}$ of hardiness by 2 and 5 DOD respectively. Rhododendron viscosum var. montanum also lacked dehardening resistance; it dehardened by $6.7^{\circ} \mathrm{C}$ and $14.6{ }^{\circ} \mathrm{C}$ by 2 and 10 DOD respectively. Rhododendron canescens lost $6.1^{\circ} \mathrm{C}$ of hardiness by 5 DOD. Rhododendron arborescens exhibited greater dehardening resistance; it only lost $2.7^{\circ} \mathrm{C}$ and $4.3^{\circ} \mathrm{C}$ of hardiness by 2 and 10 DOD respectively, and required 15 DOD to deharden by $8.8^{\circ} \mathrm{C}$.

REHARDENING CAPACITIES. None of the genotypes rehardened at either 2 or 5 DOD at any of the three rehardening temperatures (indicated by "+" prefix to rehardening capacities in Table 2), but some rehardening was observed at 10 and 15 DOD (indicated by “"” prefix to rehardening capacities in Table 2). Actual $\mathrm{LT}_{50}$ values after various rehardening treatments are not shown here. Rhododendron viscosum var. montanum rehardened after 10 DOD at all three temperatures, but it did so more effectively at 2 to $4{ }^{\circ} \mathrm{C}$ than at $-2{ }^{\circ} \mathrm{C}$ (Table 2). Both $R$. arborescens and $R$. viscosum var. montanum rehardened after 15 DOD when exposed to either $0{ }^{\circ} \mathrm{C}$ or $-2{ }^{\circ} \mathrm{C}$, but not 2 to $4{ }^{\circ} \mathrm{C}$ (Table 2). For either genotype after 10 or 15 DOD, however, there were no differences in the rehardening capacities at $0{ }^{\circ} \mathrm{C}$ vs. $-2{ }^{\circ} \mathrm{C}$ (Table 2). For $R$. viscosum var. montanum rehardened at either $0{ }^{\circ} \mathrm{C}$ or $-2{ }^{\circ} \mathrm{C}$, there was no difference between the rehardening capacities at 10 DOD versus 15 DOD (Table 2). Moreover, when comparing the two genotypes after $15 \mathrm{DOD}$, no differences between the rehardening capacities were observed at either $0{ }^{\circ} \mathrm{C}$ or $-2{ }^{\circ} \mathrm{C}$ (Table 2$)$.

Water CONTENT vS. DAYS OF DEHARDENING. Water content increased with DOD for $R$. arborescens, $R$. canadense, and $R$. viscosum var. montanum and var. serrulatum (Table 3). However, all genotypes reached relatively stable water contents after several DOD: 2 DOD for $R$. viscosum var. serrulatum, 5 DOD for $R$. arborescens and $R$. viscosum var. montanum, and 10 DOD for $R$. canadense (Table 3 ). The two $R$. viscosum ecotypes exhibited the same water content at $0,2,10$, and 15 DOD (Table 3). The hardiness of $R$. arborescens, $R$. canadense, and $R$. viscosum var. montanum was negatively associated with the bud water content (i.e., hardiness was higher at lower water content; Fig. 2). The hardiness of $R$. viscosum var. serrulatum was not determined. Although the water content at 0 DOD was ranked in the order $R$. viscosum var. montanum $<R$. canadense $<R$. arborescens (Table 3 ), the hardiness ranking of the three genotypes was in precisely the reverse order (Table 1). Although a similar relationship of relative hardiness to relative water content among genotypes was observed at 2 DOD, at 10 and 15 DOD the more cold-hardy $R$. arborescens exhibited a higher water content than did the less-hardy $R$. viscosum var. montanum (Tables 1 and 3).

Chilling ReQuirements. Rhododendron canadense was found to have the lowest CR for endodormancy (450 CU). Rhododendron atlanticum, $R$. austrinum, and $R$. canescens had respective $\mathrm{CRs}$ of 820,830 , and $830 \mathrm{CU}$, whereas $R$. calendulaceum exhibited a CR of $1000 \mathrm{CU}$. A total of 1095 CU were accumulated by 22 Feb. 2006, the bud collection date for the dehardening and rehardening study. Consequently, $R$. canadense and $R$. canescens had completed endodormancy before being artificially dehardened, whereas $R$. viscosum var. montanum and $R$. arborescens had not. Budbreak was also 
Table 1. Effect of days of dehardening (DOD) on floral bud cold hardiness [the subfreezing temperature in degrees Celsius killing $50 \%$ of florets $\left.\left(\mathrm{LT}_{50}\right)\right]$ in four Rhododendron genotypes.

\begin{tabular}{|c|c|c|c|c|c|}
\hline \multirow[b]{3}{*}{ Rhododendron genotype } & \multicolumn{5}{|c|}{ Time (DOD) } \\
\hline & 0 & 2 & 5 & 10 & 15 \\
\hline & \multicolumn{5}{|c|}{$\mathrm{LT}_{50}\left({ }^{\circ} \mathrm{C}\right)$} \\
\hline R. arborescens & $-30.4 \pm 0.0^{\mathrm{z}}$ & $-27.7 \pm 0.4 \mathrm{a}^{\mathrm{y}}$ & $-x$ & $-26.1 \pm 0.5$ & $-21.6 \pm 0.1$ \\
\hline R. canadense & $-33.6 \pm 0.3$ & $-25.9 \pm 0.3$ & $-15.3 \pm 1.8$ & $\mathrm{ND}^{\mathrm{w}}$ & ND \\
\hline R. canescens & $-24.4 \pm 0.3 \mathrm{~b}^{\mathrm{v}}$ & $-23.6 \pm 0.2 b$ & $-18.3 \pm 0.3$ & ND & ND \\
\hline R. viscosum var. montanum & $-35.8 \pm 0.3$ & $-29.1 \pm 0.6 \mathrm{a}$ & - & $-21.2 \pm 1.0$ & $-19.7 \pm 0.3$ \\
\hline
\end{tabular}

${ }^{\mathrm{z}}$ Differences among the temperature killing $50 \%$ of florets $\left(\mathrm{LT}_{50}\right)$ were assessed using an LSD procedure.

${ }^{\mathrm{y}}$ Means \pm SE within each column followed by "a" are not different from one another at $P \leq 0.05$ with an LSD of 1.5 .

${ }^{\mathrm{x}}$ Treatments at which the $\mathrm{LT}_{50}$ with SE could not be determined are marked with a hyphen. In some cases, the $\mathrm{LT}_{50}$ could not be estimated precisely (i.e., a large SE) because of the high variability in bud freezing injury resulting from particular profile temperatures. In other cases, the freezing injury data were highly invariable (either $0 \%$ or $100 \%$ injury was observed for a given temperature) and the slope of the rising section of the logistic curve could not be estimated accurately because of an absence of data. As a result, in these cases the SE could not be calculated and the reliability of the $\mathrm{LT}_{50}$ estimate could not be assessed.

${ }^{\text {w}}$ Treatments at which the $\mathrm{LT}_{50}$ was not determined because of lack of buds ( $R$. canescens) or advanced bud development ( $R$. canadense) are labeled as ND.

"Means \pm SE within each row followed by "b" are not different from one another at $P \leq 0.05$ with an LSD of 1.5.

$\mathrm{LT}_{50}$ values represent a 32-bud cold hardiness evaluation at eight profile temperatures. DOD, days of dehardening.

Table 2. Rehardening capacities $\left(\Delta^{\circ} \mathrm{C}\right.$-in other words, the increase in cold hardiness of dehardened buds after rehardening) of four Rhododendron genotypes after 2, 5, 10, or $15 \mathrm{~d}$ of dehardening (DOD) and subsequent rehardening (RHD) for $1 \mathrm{~d}$.

\begin{tabular}{|c|c|c|c|c|c|c|c|c|c|c|c|c|}
\hline \multirow{2}{*}{$\begin{array}{l}\text { Rhododendron genotype } \\
\text { Rehardening } \\
\text { temperature }\left({ }^{\circ} \mathrm{C}\right) \\
\end{array}$} & \multicolumn{3}{|c|}{$2 \mathrm{DOD} \rightarrow \operatorname{RHD}\left(\Delta^{\circ} \mathrm{C}\right)$} & \multicolumn{3}{|c|}{$5 \mathrm{DOD} \rightarrow \operatorname{RHD}\left(\Delta^{\circ} \mathrm{C}\right)$} & \multicolumn{3}{|c|}{$10 \mathrm{DOD} \rightarrow \operatorname{RHD}\left(\Delta^{\circ} \mathrm{C}\right)$} & \multicolumn{3}{|c|}{$15 \mathrm{DOD} \rightarrow \operatorname{RHD}\left(\Delta^{\circ} \mathrm{C}\right)$} \\
\hline & $2-4$ & 0 & -2 & $2-4$ & 0 & -2 & $2-4$ & 0 & -2 & $2-4$ & 0 & -2 \\
\hline$R$. arborescens & $-\mathrm{z}$ & - & - & - & - & - & $+2.6^{\mathrm{yx}}$ & +3.2 & +2.6 & $-1.3 \mathrm{a}^{\mathrm{w}}$ & $-2.3 \mathrm{am}^{\mathrm{v}}$ & -2.0 an \\
\hline R. canescens & +5.6 & $\mathrm{ND}$ & +0.7 & +4.6 & ND & +3.4 & ND & ND & ND & ND & ND & ND \\
\hline R. viscosum var. & +2.0 & -0.6 & +2.2 & - & - & - & $-4.1 \mathrm{a}$ & $-3.1 \mathrm{abd}$ & -2.1 be & +0.6 & $-2.5 \mathrm{cdm}$ & -2.9 cen \\
\hline
\end{tabular}

R. viscosum var.

ontanum

${ }^{\mathrm{z}}$ Treatments at which the temperature killing $50 \%$ of florets $\left(\mathrm{LT}_{50}\right)$ and/or se could not be reliably determined are marked with a hyphen. In some cases, the $\mathrm{LT}_{50}$ could not be estimated precisely (i.e., a large $\mathrm{SE}$ ) because of the high variability in bud freezing injury resulting from particular profile temperatures. In other cases, the freezing injury data were highly invariable (either $0 \%$ or $100 \%$ injury was observed for a given temperature) and the slope of the rising section of the logistic curve could not be estimated accurately because of an absence of data. As a result, in these cases the SE could not be calculated and the reliability of the $\mathrm{LT}_{50}$ estimate could not be assessed.

y Temperature killing 50\% of florets before rehardening (RHD) at 2, 5, 10, and $15 \mathrm{~d}$ of dehardening (DOD) for these genotypes are given in Table 1 . ${ }^{x}$ Differences among $\mathrm{LT}_{50}$ were assessed using an LSD procedure. Because the LSD was assessed as 1.5 with a $P \leq 0.05$, genotypes with a rehardening capacity $\geq| \pm 1.5|$ represent a statistically significant change in hardiness. However, only negative values for rehardening capacity represent actual rehardening.

wValues within each row followed by the same letter (a, b, c, d, e) are not different at $P \leq 0.05$ with an LSD of 1.5 . Statistical comparisons are only shown when actual rehardening occurred in at least one of the treatments.

${ }^{v}$ Means within each column followed by the same letter $(\mathrm{m}, \mathrm{n})$ are not different at $P \leq 0.05$ with an LSD of 1.5 . Statistical comparisons are only shown when actual rehardening occurred in at least one of the treatments.

"Treatments at which the $\mathrm{LT}_{50}$ was not determined because of the lack of buds ( $R$. canescens) or advanced bud development ( $R$. canadense) are labeled as ND.

Rehardening capacities are shown for three rehardening temperatures $\left(2\right.$ to $4{ }^{\circ} \mathrm{C}, 0{ }^{\circ} \mathrm{C}$, and $\left.-2{ }^{\circ} \mathrm{C}\right)$ and represent the difference between $\mathrm{LT}_{50}$ (the subfreezing temperature killing $50 \%$ of florets) values calculated from 32-bud cold hardiness evaluations at eight profile temperatures made before and after rehardening.

monitored for the Rhododendron genotypes arborescens, prinophyllum, prunifolium, viscosum var. montanum, and viscosum var. serrulatum. However, none of these exhibited 50\% budbreak by the end of the study (13 Mar. 2006; $1182 \mathrm{CU}$ accumulated), and therefore CR could not be calculated. Of these five genotypes, only $R$. prinophyllum showed signs of budbreak $(25 \%)$ by 13 Mar. 2006. The CR data obtained in this study are in accordance with anecdotal observations (650-1350 CU) made on many azalea species (Lee, 1965).

\section{Discussion}

Midwinter haRdiness. Comparison of the results of the current study with those obtained in Kalberer et al. (2006a) reveal several important differences. With the exception of $R$. canescens, the bud hardiness of other genotypes at 0 DOD (i.e., midwinter hardiness) was about 4 to $8^{\circ} \mathrm{C}$ greater in Feb. 2006 than in Dec. 2004 (Table 1; this study) (Kalberer et al., 2006a). It is possible that the buds in 2004 were not exposed to enough cold weather (September to December) to allow maximal hardening before the start of the experiment. Additionally, we believe that the azalea shrubs used in this study were better established in 2006 than in 2004. The azaleas were planted as balled and burlap-wrapped shrubs only about 3 months before buds were collected for the 2004 study (Kalberer et al., 2006a). Reduced growth and vigor often result from the loss of roots during transplanting (Struve, 1990). Inadequate root establishment can result in insufficient water uptake and 
Table 3. Effect of days of dehardening (DOD) on floral bud water content in four Rhododendron genotypes.

\begin{tabular}{|c|c|c|c|c|c|}
\hline \multirow[b]{3}{*}{ Rhododendron genotype } & \multicolumn{5}{|c|}{ Time (DOD) } \\
\hline & 0 & 2 & 5 & 10 & 15 \\
\hline & \multicolumn{5}{|c|}{ Water content ( $\%$ fresh wt) } \\
\hline R. arborescens & $47.3 \pm 0.7^{\mathrm{z}} \mathrm{a}^{\mathrm{y}}$ & $49.2 \pm 0.5 \mathrm{ab}$ & $51.9 \pm 0.5 \mathrm{bc}$ & $54.2 \pm 0.4 \mathrm{c}$ & $53.8 \pm 0.5 \mathrm{c}$ \\
\hline$R$. canadense & $31.2 \pm 2.0$ & $42.0 \pm 1.3 \mathrm{~m}^{\mathrm{x}}$ & $47.9 \pm 1.0 \mathrm{~m}$ & $60.0 \pm 1.9 \mathrm{a}$ & $61.5 \pm 1.4 \mathrm{a}$ \\
\hline R. viscosum var. montanum & $25.5 \pm 1.1 \mathrm{~m}$ & $44.3 \pm 1.5 \mathrm{~m}$ & $47.5 \pm 1.0 \mathrm{am}$ & $48.3 \pm 0.9 \mathrm{am}$ & $47.3 \pm 0.9 \mathrm{am}$ \\
\hline R. viscosum var. serrulatum & $26.8 \pm 3.7 \mathrm{~m}$ & $44.4 \pm 1.4 \mathrm{am}$ & $43.7 \pm 2.4 \mathrm{a}$ & $49.9 \pm 0.7 \mathrm{~m}$ & $45.7 \pm 1.1 \mathrm{am}$ \\
\hline
\end{tabular}

${ }^{\mathrm{z}}$ Differences among treatments were assessed using an LSD procedure.

${ }^{\mathrm{y}}$ Means \pm SE within each row followed by a, $\mathrm{b}$, or $\mathrm{c}$ are not different from one another at $P \leq 0.05$ with an LSD of 2.9 .

"Means \pm SE within each column followed by " $\mathrm{m}$ " are not different from one another at $P \leq 0.05$ with an LSD of 2.9 .

Water content is measured as percentage of fresh weight, and represents the mean for 10 individual buds. DOD, days of dehardening.

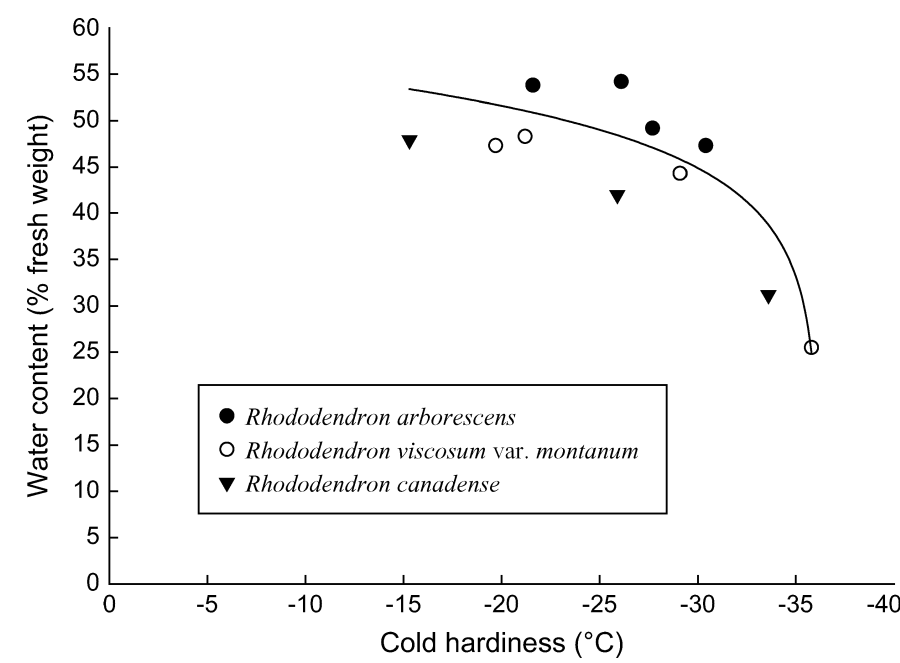

Fig. 2. Water content of floral buds (percent fresh weight) as a function of cold hardiness [the subfreezing temperature in ${ }^{\circ} \mathrm{C}$ killing $50 \%$ of florets $\left(\mathrm{LT}_{50}\right)$ ] for Rhododendron arborescens, $R$. viscosum var. montanum, and $R$. canadense. Each point represents the mean for 10 buds. The data for the three genotypes were combined and modeled using a single log-linear equation: water content $(\%$ fresh weight $)=32.2+7.0\left[\ln \left(\mathrm{LT}_{50}+36.2\right)\right] ; R^{2}=0.71$.

subsequent winter stress (Ball, 1987). However, Galle (1974) records the folk wisdom that azaleas are easily transplanted during autumn or winter, and Struve (1990) found that plants with fibrous root systems (e.g., azaleas) transplant relatively easy because of many intact root tips and primary lateral roots.

Dehardening PatTerns. It is noteworthy that the hardiest genotypes at 0 DOD, $R$. viscosum var. montanum and $R$. canadense, dehardened to a greater extent than did the relatively less hardy genotypes $R$. arborescens and $R$. canescens throughout the time course (Table 1). This result confirms previous findings (Arora et al., 2004; Iwaya-Inoue and Kaku, 1986; Kalberer et al., 2006a; Wolf and Cook, 1992) of a lack of association between high dehardening resistance and high midwinter hardiness.

In addition to the differences in dehardening kinetics among genotypes within the current study, there also were differences in the kinetics of the same genotype between the Dec. 2004 and Feb. 2006 studies in some cases. For example, $R$. viscosum var. montanum lost $14.6^{\circ} \mathrm{C}$ of hardiness by 10 DOD in Feb. 2006, whereas in Dec. 2004 only $3.9^{\circ} \mathrm{C}$ of hardiness was lost by 11 DOD (Table 1; this study) (Kalberer et al., 2006a). Similarly, $R$. canadense buds at 5 DOD dehardened by $18.3^{\circ} \mathrm{C}$ in the current study (Table 1), whereas they lost $8.1^{\circ} \mathrm{C}$ of hardiness after 5 DOD in the previous study (Kalberer et al., 2006a). In contrast, the initial dehardening resistance of $R$. canescens was lower in the Dec. 2004 study than in the current study; $4.7^{\circ} \mathrm{C}$ of hardiness were lost by 1 DOD in Dec. 2004 compared with only $0.8^{\circ} \mathrm{C}$ by 2 DOD in Feb. 2006 (Table 1; this study) (Kalberer et al., 2006a). Finally, the dehardening rate of $R$. arborescens was similar throughout the time course in both studies (Table 1; this study) (Kalberer et al., 2006a).

Previous research suggests that dehardening resistance is correlated to the depth of bud dormancy in many species [e.g., tart cherry (Prunus cerasus L.) (Callan, 1990), R. kiusianum Mak. (Iwaya-Inoue and Kaku, 1986), red-osier dogwood (Cornus sericea L.) (Tanino et al., 1989), and grape (Vitis L.) (Wolf and Cook, 1992)]. Therefore, it is conceivable that the reduced depth of bud endodormancy in Feb. 2006 (relative to Dec. 2004) is partly responsible for the lower dehardening resistance of $R$. canadense and $R$. viscosum var. montanum in Feb. 2006 compared with Dec. 2004. However, in the current study there was no consistent relationship between the depth of endodormancy and dehardening resistance. Although both genotypes exhibited a similarly large decline in dehardening resistance in Feb. 2006, $R$. canadense (450 CU) had broken endodormancy at this date whereas $R$. viscosum var. montanum had not. Similar exceptions to an association between dormancy depth and dehardening resistance have been observed in blueberry (Vaccinium L.) (Arora et al., 2004; Rowland et al., 2005).

Results of this study indicate that the genotypes with greater acclimated hardiness ( $R$. canadense, $R$. viscosum var. montanum) lost dehardening resistance as winter progressed, whereas the more sensitive genotypes ( $R$. canescens, $R$. arborescens) were still relatively slow to deharden in Feb. 2006. This is a rather intriguing combination of cold hardiness attributes. As discussed more fully later, genotypes with high midwinter hardiness may experience less selective pressure to evolve strong dehardening resistance or rehardening capacity than do more sensitive genotypes, because the former can safely lose larger amounts of acclimated hardiness before becoming vulnerable to cold injury.

RehaRdening CAPACITIES. Controlled rehardening of buds after dehardening was only observed after 10 and 15 DOD in $R$. viscosum var. montanum and 15 DOD in $R$. arborescens (Table 2). No rehardening was observed in $R$. canadense or $R$. canescens up to $5 \mathrm{DOD}$, after which no rehardening data were collected (Table 2). In contrast, rehardening was possible in the Dec. 2004 study even after only 1 DOD (Kalberer et al., 2006a). The inability of buds to reharden until exposed to a relatively long dehardening duration suggests that during the late winter (Feb. 2006) rehardening ability is influenced by the "stage of dehardening" (i.e., buds reharden only after a 
"threshold" level of dehardening). In the physiological context, perhaps levels of certain proteins/compatible solutes may need to decrease, or tissue hydration may need to increase, beyond a certain threshold during dehardening before the plant can respond to a renewed exposure to cold and reharden.

In support of the "rehardening ability vis-a-vis dehardening stage" concept, the final hardiness in $R$. arborescens after rehardening at $-2{ }^{\circ} \mathrm{C}$ after $15 \mathrm{DOD}\left(-23.6{ }^{\circ} \mathrm{C}\right)$ was not different from $(\mathrm{LSD}=1.5)$ that after an identical rehardening regime after 10 DOD $\left(-23.5^{\circ} \mathrm{C}\right)$. It is noteworthy that although rehardening occurred after 15 DOD, it did not after 10 DOD (Table 2). Similarly, for $R$. viscosum var. montanum, the hardiness after 2 DOD and subsequent failed rehardening at $-2{ }^{\circ} \mathrm{C}\left(-26.9^{\circ} \mathrm{C}\right)$ was greater $(\mathrm{LSD}=1.5)$ than the hardiness after 10 or 15 DOD and subsequent successful rehardening $\left(-23.3^{\circ} \mathrm{C}\right.$ and $-22.6{ }^{\circ} \mathrm{C}$ respectively). In other words, even when rehardening was unsuccessful at early dehardening stages, these buds were at least as hardy as those that were successfully rehardened at later stages of dehardening. Assuming that the rehardening at later stages of dehardening is sufficient to prevent cold injury, the lack of rehardening at earlier dehardening stages should not compromise winter survival. It appears, therefore, that rehardening is perhaps not an essential adaptation if the hardiness after dehardening is still greater than the minimum level required for winter survival.

In the Dec. 2004 study, rehardening capacities were greater than those observed in the Feb. 2006 study. For example, $R$. viscosum var. montanum exhibited rehardening capacities of $-3.9,-11.0,-2.6$, and $-2.3{ }^{\circ} \mathrm{C}$ after $1,3,5$, and 8 DOD respectively, when rehardened at $2{ }^{\circ} \mathrm{C}$ and $-2{ }^{\circ} \mathrm{C}$ for $12 \mathrm{~h}$ each in the Dec. 2004 study (Kalberer et al., 2006a). This genotype, when rehardened for $24 \mathrm{~h}$ at $-2{ }^{\circ} \mathrm{C}$, in 2006 , exhibited the maximum rehardening capacity of $-2.9^{\circ} \mathrm{C}$ after 15 DOD (Table 2). During Dec. 2004, rehardening was observed after 1 DOD in $R$. canadense, $R$. viscosum var. montanum, and $R$. viscosum var. serrulatum, and continued up to 8 DOD (Kalberer et al., 2006a). Hence, in contrast to the current study, in Dec. 2004, rehardening could occur even at very early stages of dehardening.

The rehardening capacity declined as endodormancy became shallower in both Viburnum plicatum Thunb. (Irving and Lanphear, 1967) and Scots pine (Pinus sylvestris L.) (Leinonen et al., 1997). The difference in rehardening abilities between the Dec. 2004 and Feb. 2006 studies, therefore, could be related to differences in the depth of endodormancy in two studies, with a greater dormancy depth in Dec. 2004 promoting rehardening even after low levels of dehardening. This interpretation is supported by the fact that the only genotypes in the current study to exhibit rehardening ( $R$. arborescens and $R$. viscosum var. montanum) were also those that had not fulfilled their CR by the experimental sampling date (22 Feb. 2006). Additionally, it is likely that the greater midwinter hardiness attained in Feb. 2006 (than Dec. 2004) allowed these buds to deharden to a greater degree and delay rehardening while still remaining hardy enough to survive prevalent conditions.

Contrary to expectations, there was no effect of the rehardening temperature on the rehardening capacity (Table 2 ). In the case of $R$. viscosum var. montanum, 2 to $4{ }^{\circ} \mathrm{C}$ was a more effective rehardening temperature than $-2{ }^{\circ} \mathrm{C}$ after $10 \mathrm{DOD}$, but the reverse was true after 15 DOD (Table 2). The rehardening temperatures $\left(2\right.$ to $\left.4{ }^{\circ} \mathrm{C}, 0{ }^{\circ} \mathrm{C},-2{ }^{\circ} \mathrm{C}\right)$ or the rehardening duration $(24 \mathrm{~h})$ chosen in this study may not have been different enough or long enough, respectively, to resolve small but significant differences, if any, among these treatments.

W ATER CONTENT AND DEHARDENING. Bud water content and hardiness are inversely related such that reduced water content is associated with increased bud hardiness (Fig. 2); this finding is consistent with many studies (Rapacz, 2002; Webster and Ebdon, 2005). Although the relative hardiness of genotypes at a given DOD was associated with differences in water content among them early in the time course (0-2 DOD), by 10 DOD this was no longer the case for $R$. arborescens and $R$. viscosum var. montanum (Tables 1 and 3 ). The relationship between water content and hardiness may not be exact because tissue moisture can also affect hardiness indirectly through its impact on growth and development (Kalberer et al., 2006b; Rapacz, 2002), which in turn may affect hardiness. For example, although the water content of winter wheat (Triticum aestivum L.) and winter rye (Secale cereale L.) was strongly correlated with hardiness during dehardening (Gusta and Fowler, 1976a, b), this correlation was weaker during rehardening (Gusta and Fowler, 1976a). And unlike the deacclimation rate, the rate of increase in moisture content was not entirely temperature dependent (Gusta and Fowler, 1976b). Growth was not measured in the current study, but $R$. canadense was the only genotype examined for water content to complete endodormancy (450 CU for CR) and exhibit partial anthesis before 10 DOD. It is therefore not surprising that $R$. canadense had the highest bud water content of the four genotypes on 10 and 15 DOD (Table 3). Finally, the two R. viscosum ecotypes had the same bud water content throughout most of the dehardening time course (Table 3) - a reasonable outcome for an intraspecific comparison. However, although the hardiness of $R$. viscosum var. serrulatum was not evaluated in this study, it is known to be substantially more cold sensitive than botanical variety montanum and exhibits less dehardening resistance. This suggests that differences in bud hardiness of these ecotypes are not linked to their hydration status.

Chilling Requirements, Midwinter hardiness, and DEHARDENING. Data on the CR and hardiness, together, revealed that there was no apparent association between CR of azalea floral buds and their midwinter hardiness or dehardening resistance. For example, $R$. canadense, the genotype with the lowest CR $(450 \mathrm{CU})$, had high midwinter hardiness $\left(-33.6^{\circ} \mathrm{C}\right)$, whereas $R$. canescens with a CR of $830 \mathrm{CU}$ was hardy to only $-24.4{ }^{\circ} \mathrm{C}$. Furthermore, $R$. arborescens and $R$. viscosum var. montanum, with a CR that exceeded $1182 \mathrm{CU}$ (because no budbreak was evident in forcing experiments even for the 13 Mar. 2006 samples) were both close in midwinter hardiness to $R$. canadense (Table 1). Both $R$. arborescens and $R$. viscosum var. montanum shared a large $\mathrm{CR}$, but the dehardening resistance of $R$. arborescens was relatively high, whereas the low dehardening resistance of $R$. viscosum var. montanum was similar to that of the low-CR R. canadense (Table 1).

It is curious that the $\mathrm{CR}$ for $R$. canadense should be significantly lower than the CR of other genotypes used in this study. Rhododendron canadense is found further north than these other azaleas, inhabiting the northeastern United States and the maritime provinces of Canada (Towe, 2004). The seed provenance for the $R$. canadense used in this study had the lowest average minimum temperatures of all the provenances tested in the budbreak assay (Kalberer et al., 2006a). As argued in Kalberer et al. (2006a), the cold and stable maritime climate of the $R$. canadense habitat may lessen the chances of unseasonable 
(premature) dehardening. The low $\mathrm{CR}$ of $R$. canadense, which predisposes these plants to premature growth and consequent dehardening, would not be a liability in its native habitat. The growth season at northern latitudes is relatively shorter than in southern latitudes, and a high CR might be maladaptive as a result of the potential delay of growth; however, the warmtemperature requirement for growth initiation is typically more important in determining when spring growth begins (Taulavuori et al., 2004). Interestingly, Hannerz et al. (2003) noted that many types of plants with high CR often suffered more winter damage than those with low CR. They explained this to be the result of the high-CR plants finishing active growth later during the season or lack of adequate hardening during the autumn.

Most research shows that, for intraspecies ecotypes, the CR generally decreases as the climate of the provenance becomes more polar or continental. For example, CR of silver birch (Betula pendula Roth) and Scots pine from the continental climates of Finland and Russia were lower than those of plants originating on the Scottish coast (Leinonen, 1996). Among European provenances of Norway spruce [Picea abies (L.) Karst], the CR decreased as latitude increased and longitude shifted eastward away from coastal regions (Hannerz et al., 2003). High CRs are needed to prevent premature development in climates with relatively mild winters. Winters become milder (in the northern hemisphere) in the growth sites located farther south and closer to the ocean. However, it should be recognized that if plants originating in colder climates with the potential for unseasonably warm weather are compared with those from warm climates without significant winter conditions, then the association between $\mathrm{CR}$ and climate might be reversed (i.e., the $\mathrm{CR}$ would decrease as the latitude and distance to the coast decrease). In summary, the low CR of $R$. canadense is likely associated with its northern habitat.

\section{Literature Cited}

Andrews, P.K. and E.L. Proebsting, Jr. 1987. Effects of temperature on the deep supercooling characteristics of dormant and deacclimating sweet cherry flower buds. J. Amer. Soc. Hort. Sci. 112:334340.

Arora, R., L.J. Rowland, E.L. Ogden, A.L. Dhanaraj, C.O. Marian, M.K. Ehlenfeldt, and B. Vinyard. 2004. Dehardening kinetics, bud development, and dehydrin metabolism in blueberry cultivars during deacclimation at constant, warm temperatures. J. Amer. Soc. Hort. Sci. 129:667-674.

Ball, J. 1987. Influence of fall planting dates on the survival and growth of Taxus, Thuja, and Viburnum species. HortScience 22:1289-1290. Callan, N.W. 1990. Dormancy effects on supercooling in deacclimated 'Meteor' tart cherry flower buds. J. Amer. Soc. Hort. Sci. 115:982-986.

Galle, F. 1974. Southern living: Azaleas. Oxmoor House, Birmingham, Ala.

Graham, P.R. and R. Mullin. 1976. A study of flower bud hardiness in azalea. J. Amer. Soc. Hort. Sci. 101:7-10.

Gusta, L.V. and D.B. Fowler. 1976a. Dehardening and rehardening of spring-collected winter wheats and a winter rye. Can. J. Plant Sci. 56:775-779.

Gusta, L.V. and D.B. Fowler. 1976b. Effects of temperature on dehardening and rehardening of winter cereals. Can. J. Plant Sci. 56:673-678.

Hamilton, D.F. 1973. Factors influencing dehardening and rehardening of Forsythia Xintermedia stems. J. Amer. Soc. Hort. Sci. 98:221-223.
Hannerz, M., I. Ekberg, and L. Norell. 2003. Variation in chilling requirements for completing bud rest between provenances of Norway spruce. Silvae Genet. 52:161-168.

Howell, G.S. and C.J. Weiser. 1970. Fluctuations in the cold resistance of apple twigs during spring dehardening. J. Amer. Soc. Hort. Sci. 95:190-192.

Irving, R.M. and F.O. Lanphear. 1967. Dehardening and the dormant condition in Acer and Viburnum. Proc. Amer. Soc. Hort. Sci. 91:699-705.

Ishikawa, M. and A. Sakai. 1981. Freezing avoidance mechanisms by supercooling in some Rhododendron flower buds with reference to water relations. Plant Cell Physiol. 22:953-967.

Iwaya-Inoue, M. and S. Kaku. 1986. Cold hardiness and acclimation intensity in flower buds for fall bloom and spring bloom clones in Rhododendron kiusianum, a dwarf evergreen azalea. Plant Cell Physiol. 27:515-521.

Kalberer, S.R., N. Leyva-Estrada, S.L. Krebs, and R. Arora. $2006 a$. Frost dehardening and rehardening of floral buds of deciduous azaleas are influenced by genotypic biogeography. Environ. Exp. Bot. (in press).

Kalberer, S.R., M. Wisniewski, and R. Arora. 2006b. Deacclimation and reacclimation of cold-hardy plants: Current understanding and emerging concepts. Plant Sci. 171:3-16.

Lee, F.P. 1965. The azalea book. (2nd ed) Van Nostrand, Princeton, N.J.

Leinonen, I. 1996. Dependence of dormancy release on temperature in different origins of Pinus sylvestris and Betula pendula seedlings. Scand. J. For. Res. 11:122-128.

Leinonen, I., T. Repo, and H. Hänninen. 1997. Changing environmental effects on frost hardiness of Scots pine during dehardening. Ann. Bot. (Lond.) 79:133-138.

Mahfoozi, S., A.E. Limin, and D.B. Fowler. 2001. Developmental regulation of low-temperature tolerance in winter wheat. Ann. Bot. (Lond.) 87:751-757.

Pellett, H. 1998. Breeding of cold hardy woody landscape plants, p. 317-323. In: P.H. Li and T.H.H. Chen (eds.). Plant cold hardiness: Molecular biology, biochemistry, and physiology. Plenum Press, New York.

Rapacz, M. 2002. Cold-deacclimation of oilseed rape (Brassica napus var. oleifera) in response to fluctuating temperatures and photoperiod. Ann. Bot. (Lond.) 89:543-549.

Repo, T. 1991. Rehardening potential of Scots pine seedlings during dehardening. Silva Fennica 25:13-21.

Richardson, E.A., S.D. Seeley, and D.R. Walker. 1974. A model for estimating the completion of rest for 'Redhaven' and 'Elberta' peach trees. HortScience 9:331-332.

Rowland, L.J., E.L. Ogden, M.K. Ehlenfeldt, and B. Vinyard. 2005. Cold hardiness, deacclimation kinetics, and bud development among 12 diverse blueberry genotypes under field conditions. J. Amer. Soc. Hort. Sci. 130:508-514.

Struve, D.K. 1990. Root regeneration in transplanted deciduous nursery stock. HortScience 25:266-270.

Tanino, K.K., L.H. Fuchigami, T.H.H. Chen, L.V. Gusta, and C.J. Weiser. 1989. Dormancy-breaking agents on acclimation and deacclimation of dogwood. HortScience 24:353-354.

Taulavuori, K.M.J., E.B. Taulavuori, O. Skre, J. Nilsen, B. Igeland, and K.M. Laine. 2004. Dehardening of mountain birch (Betula pubescens ssp. czerepanovii) ecotypes at elevated winter temperatures. New Phytol. 162:427-436.

Towe, L.C. 2004. American azaleas. Timber Press, Portland, Ore.

Väinölä, A., S. McNamara, and H. Pellett. 1997. Stem and flower bud hardiness of deciduous azaleas. J. Environ. Hort. 15:45-50.

Webster, D.E. and J.S. Ebdon. 2005. Effects of nitrogen and potassium fertilization on perennial ryegrass cold tolerance during deacclimation in late winter and early spring. HortScience 40:842-849.

Wolf, T.F. and M.K. Cook. 1992. Seasonal deacclimation patterns of three grape cultivars at constant, warm temperature. Amer. J. Enol. Viticult. 43:171-179. 